\title{
FERNAND BRAUDEL Y LAS CIENCIAS SOCIALES
}

\author{
Por \\ JUAN RAMÓN GOBERNA FALQUE
}

\section{RESUMEN}

Las relaciones disciplinares en el seno de las llamadas ciencias sociales no han sido nunca idílicas, más bien todo lo contrario. Las luchas por el predominio institucional han sido constantes, y los historiadores han tenido en ellas un protagonismo decisivo al pretender convertir en múltiples ocasiones al resto de las ciencias sociales en meras ciencias auxiliares de la Historia. En este artículo veremos cómo Fernand Braudel optó por mantener una política de diálogo con cada una de las grandes ramas de las ciencias sociales con unos fines claramente estratégico-corporativos.

\section{PALABRAS CLAVE}

Teoría de la Historia, Historiografía francesa, Fernand Braudel, Epistemología de las ciencias sociales.

\section{ABSTRACT}

The disciplinary relations in the so called Social Sciences have not been never idyllic, but rather quite the opposite. The fights in order to

«CUADERNOS DE ESTUDIOS GALLEGOS», Tomo XLIX, Fascículo 115, Santiago 2002. 
obtain the institutional predominance have been constant, and the historians have had a decisive role in them, trying to turn the rest of Social Sciences into mere auxiliary sciences of History. In this article we will see how Fernand Braudel chose to maintain a dialogue with each one of the main branches of Social Sciences with clearly strategic-corporative aims.

\section{KEYWORDS}

Theory of History; French Historiography; Fernand Braudel; Epistemology of History.

El estudio de los mecanismos institucionales y sociales de la escuela de los Annales durante el periodo en el que ejerció su magisterio e influencia Fernand Braudel pone de manifiesto en qué medida se fomentó un cierto espíritu imperialista por parte de la corporación de los historiadores franceses, que no dejaron de reivindicar el estatuto privilegiado de la historia, haciendo de ella una especie de encrucijada necesaria para el conjunto de las ciencias sociales ${ }^{1}$. François Dosse lo corroboró al afirmar que «para Braudel la sexta sección (VIe Section de l'École Pratique des Hautes Études, germen de la actual École des Hautes Études en Sciences Sociales) fue un instrumento decisivo en un proceso más amplio de ingestión de las ciencias sociales en beneficio del historiador; en su estrategia no dejó de haber cierto canibalismo» ${ }^{2}$. De este modo, poco antes de morir, Braudel aseguraba: «Hay que comprender lo que es la lección de Annales, de la escuela de Annales (...), que todas las ciencias humanas sean incorporadas a la historia y se conviertan en ciencias auxiliares $\iota^{3}$. Para conseguirlo, como veremos en este artículo, Braudel utilizó la táctica del diálogo.

\footnotetext{
${ }^{1}$ Sobre este tema véase mi artículo «La cofradía de los historiadores. Estudio de los mecanismos institucionales y sociales de la escuela de los Annales durante la era Braudel», Historia y Crítica, IV, 1994, pp. 85-120.

${ }^{2}$ F. Dosse, La Historia en migajas, Valencia, Alfons el Magnànim, 1988 (París, 1987), p. 128.

${ }^{3}$ F. Braudel, Une leçon d'histoire de F. Braudel, París, Arthaud-Flammarion, 1986, p. 222.
}

«CUADERNOS DE ESTUDIOS GALLEGOS», Tomo XLIX, Fascículo 115, Santiago 2002. 


\section{PRIMER DIÁLOGO: HISTORIA ADVERSUS GEOGRAFÍA}

En primer lugar, con la geografía: «El espacio de las civilizaciones constituye algo muy diferente de un accidente; si supone un reto, es un reto repetido, de larga duración $»^{4}$. Es deudor Braudel, en esta perspectiva, de su maestro y valedor académico Lucien Febvre, quien insistía en subrayar en el fondo de cada civilización los vínculos vitales e infinitamente repetidos con el medio que crean unas relaciones elementales, y en cierta manera todavía primarias, con los diferentes tipos de suelo, los vegetales, las poblaciones animales, las endemias...

Las civilizaciones son espacios ${ }^{5}$. Esa es una de las máximas más repetidas y paradigmáticas del pensamiento de Braudel. La civilización «se aferra a un espacio determinado, que es uno de los indispensables componentes de su realidad. Antes de llegar a ser esa unidad en las manifestaciones del arte, en las que Nietzsche veía su verdad más importante (quizá porque, de acuerdo con su época, consideraba el arte como sinónimo de la calidad), una civilización es, en su base, un espacio trabajado, organizado por los hombres y por la historia. Por eso hay límites culturales, espacios culturales, de una extraordinaria perennidad; nada pueden contra ellos todas las confusiones y mezclas del mundo» ${ }^{6}$. Según nos dice Braudel, siempre es posible localizar las civilizaciones en un mapa, sea cual sea su tamaño, tanto a las civilizaciones ricas como a las pobres.

Un aspecto esencial de su realidad dependería, por tanto, de las sujeciones o ventajas determinadas por su medio geográfico: «Está claro que este medio ha sido transformado por el hombre desde hace siglos, casi

\footnotetext{
${ }^{4}$ F. Braudel, «Aportación de la historia de las civilizaciones», en La Historia y las ciencias sociales, Madrid, Alianza Editorial, 1968 (París, 1969), p. 180.

${ }^{5} \mathrm{~F}$. Braudel, Las civilizaciones actuales. Estudio de historia económica y social, Madrid, Tecnos, 1966 (París, 1963), p. 23.

${ }^{6} \mathrm{~F}$. Braudel, El Mediterráneo y el mundo mediterráneo en la época de Felipe II, México, Fondo de Cultura Económica, 1966 ( $2^{\mathrm{a}}$ ed., corregida y aumentada), $\left(1^{\mathrm{a}} \mathrm{ed}\right.$., París, 1953), p. 159. Y también tenemos esta otra cita: «¿Qué hemos de todo esto, sino que la primera realidad de una civilización es el espacio que le impone su crecimiento vegetativo y, a veces, con gran rigor, sus límites? Las civilizaciones son, ante todo, espacios, zonas y no solamente en el sentido en el que lo entienden los etnógrafos cuando nos hablan de la zona del hacha de dos filos o de la fecha emplumada, sino, digamos, de los espacios que constriñen al hombre a quien nutren y que son interminablemente trabajados por él», op. cit., p. 162.
} 
podría decirse que desde hace milenios. En todos los paisajes quedan huellas de este trabajo continuo, que se va perfeccionando con cada nueva generación. Se va, en suma, capitalizando» ${ }^{7}$.

$\mathrm{Al}$ hablar de civilizaciones, Braudel nos habla de espacios, de tierras, de relieves, de climas, de vegetaciones, de especies animales, de prerrogativas dadas o adquiridas. $Y$ de todas las consecuencias que esto tiene para el hombre: agricultura, ganadería, alimentos, casas, trajes, comunicaciones, industria... El escenario en el que tienen lugar estas interminables obras de teatro condiciona en parte su desarrollo, explica sus peculiaridades; los hombres pasan, pero el medio permanece relativamente igual a sí mismo ${ }^{8}$.

Braudel cree que el medio natural y transformado por el hombre no es el único factor de condicionamientos, que de antemano lo encierra todo en un rígido determinismo: «Aun siendo un factor importante, bajo la forma de ventajas, tanto dadas como adquiridas, no todo lo explica el medio»?

$\mathrm{Y}$ es que, en efecto, como tantos otros historiadores, Braudel se plantea muy a menudo, a lo largo de su vasta obra, el problema del determinismo geográfico ${ }^{10}$. Para los geógrafos contemporáneos de Braudel, el elemento decisivo era, no la tierra, la naturaleza o el medio, sino la historia, es decir, el hombre, el hombre prisionero de sí mismo, en defini-

\footnotetext{
${ }^{7}$ Ibid.

${ }^{8}$ Sin embargo, a nuestro modo de ver, adoptando el punto de vista de José Carlos Bermejo, el posicionamiento teórico de Braudel es algo discutible. Dentro del conjunto del pensamiento filosófico europeo había quedado muy claro a partir de Kant que la noción de espacio es simplemente una «intuición pura a priori», una noción que fue creada intelectualmente con el fin de poder analizar y comprender una realidad determinada. Sin embargo, «la mayor parte de los historiadores, influidos quizá por los elementos que llevó consigo el sistema de la mecánica newtoniana, siguen disfrutando, imaginándose que el espacio existe, que es una sustancia y que, como dice Fernand Braudel, «las civilizaciones son espacios»». Cf. J. C. Bermejo Barrera, Psicoanálisis del conocimiento histórico, Madrid, Akal, 1983, pp. 151-152. Un enfoque más completo del estudio del espacio en el conocimiento histórico lo constituye su artículo «Sobre las dimensiones significativas del espacio», en VV. AA., Concepcións espaciais e estratexias territoriais na historia de Galicia, Santiago de Compostela, Tórculo Edicións, 1992, pp. 5-22.

${ }^{9}$ F. Braudel, Las civilizaciones actuales, op. cit., p. 24.

${ }^{10}$ La definición de determinismo de Braudel es, como todas sus definiciones, cómoda y ambigua: «El determinismo es que un cierto número de causas arrastra un cierto número de consecuencias», F. Braudel, Una lección de Historia de Fernand Braudel, México, Fondo de Cultura Económica, 1989 (París, 1986), p. 257.
} 
tiva, pues es el heredero y el continuador de actos, de hechos y acciones, de técnicas y tradiciones de quienes lo precedieron en su propia tierra y de quienes modelaron su paisaje comprometiéndolo de antemano a una serie de determinismos retrospectivos de los cuales ese hombre raramente tiene conciencia. Braudel, sin embargo, siempre estuvo convencido y espantado del enorme peso que tienen los remotos orígenes. Esos orígenes nos aplastan, nos dice. Pero si bien, en su opinión, eso es cierto, ello no implica que tengamos que atribuirlo todo al pasado. Esto significaría ni más ni menos divorciarla de su geografía, de su espacio; significaría «desespacializarla» ${ }^{11}$, y esto sería absurdo para Braudel: «Francia ha surgido de una prodigiosa acumulación de historia, es verdad, pero esa acumulación se realizó en un determinado lugar, no en otro. La posición particular, curiosa, que ocupa Francia en las coyunturas de Europa, el hecho de que Europa la envuelva, todo eso desempeñó su papel» ${ }^{12}$.

En este sentido, Braudel es deudor de las enseñanzas de la geografía de Pierre Vidal de la Blache, el más ilustre representante de la escuela geográfica francesa de principios del siglo XX, para quien «la historia de un pueblo es inseparable de la comarca en que vive ese pueblo. Hay que partir de esta idea, la idea de que una comarca es un depósito en el que están dormidas energías cuyo germen ha depositado la naturaleza pero cuyo empleo depende del hombre ${ }^{13}$. Pero además, Braudel tiene otro maestro, y no duda en reconocerlo abiertamente. Este no es otro que Lucien Febvre. En efecto, el tema del determinismo geográfico sitúa a Braudel en la línea del «posibilismo», término que el propio Febvre había forjado para definir el pensamiento de Vidal de la Blache: «Una Francia posible, varias Francias posibles, éstas son fórmulas que no me desagradan ${ }^{14}$. El Lucien Febvre de La Tierra y la evolución humana no había llegado hasta

\footnotetext{
${ }^{11}$ «Muchos geógrafos [consideran] que el espacio contiene una experiencia humana muy variable. Entonces, retiran la experiencia humana y se olvidan del espacio. Los acuso de desespacializar la historia. Poniendo las cosas en su lugar, tengo el sentimiento de devolver a la geografía sus antiguos derechos, se llame o no determinismo», F. Braudel, Una lección de Historia de Fernand Braudel, op. cit., p. 255.

${ }^{12}$ F. Braudel, La identidad de Francia, I, Barcelona, Editorial Gedisa, 1993 (París, 1986), p. 257.

${ }^{13}$ P.Vidal de la Blache, Tableau de la géographie de la France, París, 1913 (reeditado en 1979), p. 8.

${ }^{14}$ F. Braudel, La identidad de Francia, op. cit., I, p. 258.
} 
la negación pura y simple del espacio. Su «posibilismo» no es otra cosa que un determinismo endulzado, pero todavía es un determinismo, al fin y al cabo. De manera que, según Braudel, aunque tengamos medios para escapar de las más fuertes coacciones del espacio, no lo suprimimos: «La historia de Francia se ha desarrollado en un cierto espacio. No me gusta la palabra Hexágono, pero el Hexágono está allí» ${ }^{15}$.

Bajo el signo de ventajas naturales, toda civilización sería consecuencia de los privilegios inmediatos pronto aprovechados por el hombre. Así, las civilizaciones fluviales del Viejo Mundo florecieron a lo largo del río Amarillo (que dio lugar a la civilización china); del Nilo (que hizo lo propio con la civilización egipcia), etc. De la misma manera, florecieron las civilizaciones thalassocráticas, consecuencia directa del mar: Fenicia, Grecia, Roma, las civilizaciones del Norte de Europa, en torno al Báltico y al Mar del Norte, etc. De hecho, estos ejemplos demuestran la primacía de los medios de comunicación. Ninguna civilización, según Braudel, puede vivir sin movimiento propio, enriqueciéndose cada una de ellas con los intercambios y con los contactos a los que se ve obligada por una próspera vecindad.

Pero al enumerar estos éxitos culturales son sobrepasadas ya las condiciones naturales favorables, inmediatas, supuestos orígenes de la civilización. Vencer la hostilidad de los desiertos y las violentas cóleras del Mediterráneo, utilizar los vientos regulares del océano Índico, poner diques a un río supondrían, según Braudel, otros tantos esfuerzos humanos, otras tantas ventajas adquiridas, o mejor dicho conquistadas. El problema, entonces, es saber por qué han sido capaces de la feliz consecución de estas empresas unos hombres sí y otros no, en unos determinados territorios y no en otros, $\mathrm{y}$ esto a lo largo de muchas generaciones. Braudel recoge la teoría del challenge and response de Arnold Toynbee, por la que para la consecución de todo éxito humano es necesario un reto y una réplica a este reto, es necesario que la naturaleza se le presente al hombre como una dificultad a vencer; si el hombre acepta el reto, su réplica pone los cimientos de la civilización. Sería, sin embargo, necesario concluir, si se lleva esta teoría hasta sus últimas consecuencias, que cuanto más fuerte sea el reto de la naturaleza mayor será la réplica del hombre. Esto

${ }^{15}$ F. Braudel, Una lección de Historia, op. cit., p. 261.

«CUADERNOS DE ESTUDIOS GALLEGOS», Tomo XLIX, Fascículo 115, Santiago 2002. 
parece dudoso, y por ello el propio Braudel reconoce los límites de esta teoría. El hombre civilizado del siglo XX ha aceptado el reto insolente de los desiertos, de las regiones polares y ecuatoriales. Y sin embargo, a pesar de que en ellos existen intereses indudables (como es el caso del oro o del petróleo), los hombres no han conseguido hasta ahora multiplicarse en estos espacios y crear en ellos verdaderas civilizaciones. Por lo tanto, es verdad que hay reto de la naturaleza, es verdad que hay réplica del hombre, pero no es forzoso que en consecuencia surja una civilización. Por lo menos, hasta que se hayan encontrado técnicas y réplicas mejores, asegura Braudel.

Por consiguiente, cada civilización está sujeta a un ámbito y a unos límites más o menos estables; de ahí que cada una de ellas tenga una geografía particular, la suya, que implica toda una serie de posibilidades, de sujeciones dadas, algunas prácticamente permanentes, que nunca son las mismas para más de una civilización. Como resultado, tenemos una abigarrada superficie del mundo, en la que los mapas indican, a voluntad, zonas de casas de madera, de adobe, de bambú y de papel, de ladrillos o de piedras; zonas de diferentes fibras textiles: lana, algodón, seda; zonas de grandes cultivos de base: arroz, maíz, trigo...; los retos varían, y de la misma manera varían las respuestas que se les dan.

La civilización occidental es la del trigo con todas las sujeciones que esto supone, ya que sabemos que el trigo es un cultivo muy exigente. Es un cultivo, en efecto, que exige una rotación anual y que se deje en reposo unas veces cada dos años y otras todos los años la tierra en donde ha sido cultivado. De la misma manera, el arrozal inundado, progresivamente extendido a las tierras bajas del Extremo Oriente, implica, también, muchas sujeciones. Por lo tanto, «las réplicas del hombre, al tiempo que le liberan del medio que le rodea, le van esclavizando a las soluciones que ha imaginado. Se libera de un determinismo para caer en otro» ${ }^{16}$.

Pero pasemos por un momento al análisis concreto que hace Braudel de ciertos accidentes geográficos para ver en qué medida exacta el peso de los condicionamientos geográficos es significativo a la hora de establecer el carácter peculiar de una civilización. Para ello nos serviremos de uno de los más clásicos estudios de Fernand Braudel, que no es otro

${ }^{16}$ F. Braudel, Las civilizaciones actuales, op. cit., p. 25. 
que el capítulo dedicado a La influencia del medio ambiente en su obra magna, El Mediterráneo y el mundo mediterráneo en la época de Felipe II.

$\mathrm{Al}$ hablar de las "características físicas y humanas» en «las montañas», Braudel asegurá que la población montañesa resulta insignificante en comparación con los vastos espacios, de difícil tránsito, que la circundan. Son centros de población «sumergidos en un espacio superabundante y en gran parte estéril u hostil, y carentes, por tanto, de contactos e intercambios, sin los cuales nunca puede renovarse la civilización» ${ }^{17}$. Se puede hablar, por tanto, de una población montañesa diluida, y más exactamente aún de una civilización incompleta, truncada, insuficiente, efecto de la escasez de población humana. Y es que, por lo general, la montaña es un mundo adusto, marginal, "situado a extramuros de las civilizaciones, que son producto de las ciudades y de las tierras llanas. Su historia consiste en no tenerla, en permanecer casi siempre al margen de las grandes corrientes civilizadoras, que discurren lentamente, pasando de largo ante el mundo de la montaña. Capaces de extenderse ampliamente en sentido horizontal, estas corrientes parecen impotentes para ascender en sentido vertical $\rangle^{18}$. Por todas partes, tanto en lo espiritual como en los demás aspectos de la civilización, encontraríamos desajuste, extraordinario rezagamiento de la vida montañesa.

Una prueba de ello la tendríamos en la facilidad con que, al amparo de circunstancias propicias, las nuevas religiones logran en las regiones altas conquistas masivas, aunque inestables. De modo que «extensas y virulentas epidemias diabólicas se extienden de un extremo a otro entre las antiguas poblaciones europeas, aterrándolas, sobre todo en las zonas altas, cuyo aislamiento las mantiene en estadios muy primitivos. Brujos, hechicerías, prácticas mágicas primitivas, misas negras: floración de un antiguo subconsciente cultural del que la civilización de Occidente no consigue liberarse. Las montañas son el refugio por excelencia de estas culturas aberrantes, surgidas de la noche de los tiempos» ${ }^{19}$.

${ }^{17} \mathrm{~F}$. Braudel, El Mediterráneo y el mundo mediterráneo en la época de Felipe II, op. cit., I, p. 39.

${ }^{18}$ Op. cit., I, p. 40.

${ }^{19}$ Op. cit., I, p. 45. O también, esta otra afirmación: «no es de extrañar que el folklore de estas altas regiones revele una credulidad totalmente primitiva. La magia y la superstición llenan aquí la vida de todos los días, propiciando conjuntamente los arrebatos místicos y las peores supercherías», op. cit., I, p. 44.

«CUADERNOS DE ESTUDIOS GALLEGOS», Tomo XLIX, Fascículo 115, Santiago 2002. 
La conquista de la planicie habría significado, desde siempre, ante todo, triunfar sobre el agua malsana y acabar con la malaria, y después, utilizar de nuevo el agua viva, corriente, para el riego: «El hombre es el elemento operante de esta larga historia. Si drena el agua, si conquista la planicie para los cultivos, extrayendo de ella la mayor parte de sus alimentos, el paludismo retrocede... Si, por el contrario, descuida la construcción de los canales de drenaje y las acequias de riego, si a su lado se desbordan las torrenteras de la montaña, cegando las vías de circulación del agua; si, por una u otra razón, la población de la llanura disminuye y se relaja el dominio que sobre ella ejerce el campesino, la malaria se extiende sin remedio y todo lo paraliza. No tarda en hundir de nuevo la planicie en su primitiva condición de desierto y de marisma; el proceso es automático» ${ }^{20}$.

Otros accidentes geográficos que han provocado cierto determinismo de civilización son las islas. Todas estas islas, pequeñas o grandes, cualquiera que sea su forma o situación, constituirían «un medio humano coherente, en la medida en que pesan sobre ellas limitaciones análogas que las colocan a la par muy en retraso y muy adelantadas con relación a la historia general del mar; que las sitúan, siempre, de modo brutal, entro esos dos polos opuestos: el arcaísmo y la novedad $»^{21}$. Y rodeando a esas islas, el mar. El mar también sería, y lo habría sido durante largo tiempo, una separación, un obstáculo, barrera que ha sido preciso franquear: «Y esta victoria no es de las que se obtienen de una vez y para siempre; ha representado y sigue representado un esfuerzo continuo, una hazaña sin cesar renovada... Hubo de ser construido, entiéndase bien, y construido por la mano del hombre» ${ }^{22}$.

A lo largo de la obra de Braudel, por tanto, encontramos continuamente referencias a la dialéctica entre el hombre y la naturaleza: «vale la pena repetirlo: la historia no la hacen los espacios geográficos, sino los hom-

${ }^{20}$ Op. cit., I, p. 81.

${ }^{21}$ Op. cit., I, p. 196. Y es que, cuando las islas entran en contacto con el mundo exterior lo hacen de un modo brusco, «entran entonces de golpe y porrazo en un nuevo tipo de vida y de civilización, las costumbres, las modas, incluso la lengua, que han sido capaces de almacenar y conservar intactas durante largos siglos, quedan en pie como el testimonio vivo de revoluciones abolidas. $\mathrm{Y}$ es que el 'aislamiento de las islas' es una verdad muy relativa», op. cit., I, p. 197.

${ }^{22}$ Op. cit., I, p. 365. 
bres que dominan o descubren estos espacios $\rangle^{23}$. ¿Cómo explica Braudel, por ejemplo, esta unidad evidente, este ser profundo del Mediterráneo? «La explicación no es sólo la naturaleza, que ha trabajado bastante en este sentido; no es sólo el hombre, que ha unido todo obstinadamente; son al mismo tiempo los dones de la naturaleza o sus maldiciones - unas y otras en número considerable- $\mathrm{y}$, ayer como hoy, los múltiples esfuerzos de los hombres. Es decir, una suma interminable de casualidades, de accidentes, de éxitos repetidos» ${ }^{24}$. Como el propio Braudel reconoce, los neutros siempre tienen éxito, y no se inclina por ninguna de las dos vías, de modo que determinismo geográfico, sí, pero el hombre también cuenta.

Sólo al final de su vida, en La Identidad de Francia, termina Braudel por decantarse. Escribe Braudel en este libro que «el rasgo principal, que constituye una obsesión de la vida campesina, es su lucha sin fin contra las fuerzas incontrolables de la naturaleza $)^{25}$. Contra esas fuerzas y a lo largo de los siglos, el campesino acumuló sus trabajos, a la vez destrucciones y construcciones. Según esta perspectiva, nada parece más simple que admitir, según una tradición bien establecida, afirma Braudel, «la antítesis de historia y naturaleza». En realidad, el hombre mismo forma parte del mundo natural, está en la tierra, en el clima, mezclado con la vegetación, la cual se le escapa como tal pero le obedece con la condición de que el hombre comience por aceptar sus exigencias. El hombre vive en medio de la población de los animales domésticos y salvajes, depende del agua, de la energía solar. De manera que «el hombre vive de la naturaleza, lo cual significa que la naturaleza es su cuerpo, con el cual el hombre

${ }^{23}$ Op. cit., I, p. 296. «La impresión que se va imponiendo, sea justa o errada -pero que yo sospecho justa-, de que el determinismo ocasionado por la sucesión de las estaciones, evidente cuando se trata de la vida rural, se ve continuamente contrarrestado por la voluntad del hombre, particularmente en las ciudades. El invierno en el mar es un obstáculo, pero las barcas lo superan en las distancias cortas, y los grandes veleros en los viajes largos... No hay duda de que el invierno en las montañas era un obstáculo..., pese a ello, se las franquea regularmente», op. cit., I, pp. 351-352.

Este punto de vista lo vuelve a reiterar, un poco más adelante, cuando afirma: «De modo que intervienen múltiples excepciones: la vida humana responde a los dictados del medio, pero intenta a la vez evadirse de ellos y controlarlos», op. cit., I, p. 353.

${ }^{24} \mathrm{~F}$. Braudel, El Mediterráneo. El espacio y la historia, México, Fondo de Cultura Económica, 1989 (París, 1977-1978), p. 10.

${ }^{25}$ F. Braudel, La identidad de Francia, op. cit., III, p. 20.

«CUADERNOS DE ESTUDIOS GALLEGOS», Tomo XLIX, Fascículo 115, Santiago 2002. 
debe permanecer unido, y debe mantener constantes relaciones con la naturaleza para no morir ${ }^{26}$, recogiendo esta imagen de Marx, que constituye una verdadera perspectiva de la historia.

Sin embargo, hace mucho tiempo que el hombre tiene la ilusión de haberla dominado. Reconoce Braudel que hoy día no se encuentra ningún paisaje agrícola que sea «natural». Enteramente reconstruido, el paisaje es el fruto de una evolución multisecular que disimula la naturaleza misma como una vestimenta que se le hubiera echado encima. Pero, ¿podemos pretender por eso que el hombre domina a su enemiga? Braudel expone los casos de las sequías, los fríos, los ciclones, etc. Evidentemente esta dictadura se ablanda, se domestica, se utiliza. No rige toda la economía rural pero la envuelve, le impone sus ritmos, organiza sus articulaciones: «No hagamos, pues, con demasiada prisa un balance satisfactorio ${ }^{27}$. En último caso, por tanto, termina primando el aspecto negativo, la imposibilidad de vencer a la naturaleza, su impresionante presencia.

$\mathrm{Y}$ es que, al fin y al cabo, «en este terreno de las profundidades, resulta irrisorio decir que el hombre hace la historia: la sufre $)^{28}$. En el fondo, «somos herederos de un agua profunda sobre la que navegamos mal, a ciegas. Esa superficie de historia nos es propicia, sin duda: nos creemos libres en ella y la libertad es, en esencia, la ilusión feliz de ser libre, de pensar que «el hombre hace la historia», cuando la recíproca - «la historia hace al hombre»- es por desgracia más verdadera ${ }^{29}$. Esta perspectiva es decididamente conservadora, pues niega al hombre su capacidad de acción política, privilegia tanto el peso de los condicionantes de larga duración (en este caso, de los condicionantes geográficos) que hace inútil cualquier esfuerzo por luchar contra ellos. De modo que, aunque el estado del mundo no sea el ideal, tampoco puede el hombre hacer gran cosa por mejorarlo. ¿Es tan sólo una postura pesimista?

\footnotetext{
${ }^{26}$ Karl Marx, Manuscritos: Economía y filosofia, Madrid, Alianza Editorial, 1989 (1844), p. 62.

${ }^{27}$ F. Braudel, La identidad de Francia, op. cit., III, p. 22.

${ }^{28}$ F. Braudel, Escritos sobre la historia, Madrid, Alianza Editorial, 1991 (París, 1990), p. 145 .

${ }^{29}$ Op. cit., p. 156.
}

«CUADERNOS DE ESTUDIOS GALLEGOS», Tomo XLIX, Fascículo 115, Santiago 2002. 


\section{SEGUNDO DIÁLOGO: HISTORIA ADVERSUS SOCIOLOGÍA}

Las sociedades, en el pensamiento braudeliano, son las que sustentan a las civilizaciones y las animan con sus tensiones y sus progresos. Sin embargo, Braudel se pregunta si era necesario crear el término de civilización, e incluso promoverlo en el plano científico, en el caso de que fuese un sinónimo de sociedad. Arnold Toynbee emplea constantemente la palabra society en lugar de civilization. Y Marcel Mauss juzga al «concepto de civilización como mucho más confuso que el de sociedad, al que, por otra parte ese concepto supone ${ }^{30}$. La conclusión de Braudel no deja lugar a la duda: «es imposible separar a la sociedad de la civilización (y recíprocamente): ambos conceptos se refieren a una misma realidad $»^{31}$.

El concepto de sociedad supone un contenido extremadamente amplio, lo mismo que el de civilización, al que Braudel se aproxima muy a menudo. De esta manera, la civilización occidental depende de la «sociedad industrial» que es la que la da vida. Es más, «sería fácil describirla, analizando esta misma sociedad, sus grupos, sus tensiones, sus valores intelectuales y morales, sus ideales, sus regularidades, sus gustos, etc. En pocas palabras, describiendo a los hombres portadores de esta civilización, y transmisores de ella» ${ }^{32}$, y siempre se llegaría a la misma conclusión: cuando la sociedad subyacente se mueve o se transforma, la civilización se transforma y se mueve a su vez ${ }^{33}$. Recoge Braudel las tesis de

${ }^{30}$ M. Mauss, «Les civilisations. Eléments et formes», en VV. AA., Civilisation. Le Mot et l'idée, Centre International de Synthèse, París, 1930, p. 83. Sobre toda esta problemática, $c f$. Juan R. Goberna Falque, Civilización. Historia de una idea, Santiago de Compostela, Servicio de Publicacións da Universidade, 1999.

${ }^{31} \mathrm{~F}$. Braudel, Las civilizaciones actuales, op. cit., p. 27. Una vez más, Fernand Braudel reconoce sus deudas con Claude Lévi-Strauss, para quien «no corresponden a objetos distintos, sino a dos perspectivas complementarias de un mismo objeto que es descrito adecuadamente, tanto por uno de los dos términos, como por el otro, según el punto de vista que se adopte», ibid.

${ }^{32}$ F. Braudel, Las civilizaciones actuales, op. cit., p. 27.

${ }^{33}$ Esto es lo que vendría a decir el libro de Lucien Goldmann, Le Dieu Caché (París, 1955), que estudia la Francia del Siglo de Oro. Según él, las características fundamentales de una civilización están determinadas por «la visión del mundo» que adopta. En cada caso, la visión del mundo se reduce a la transcripción y a la consecuencia de las tensiones sociales dominantes. La civilización, a manera de un espejo, sería la máquina que refleja estas tensiones y estos esfuerzos. La visión trágica del mundo que predomina

«CUADERNOS DE ESTUDIOS GALLEGOS», Tomo XLIX, Fascículo 115, Santiago 2002. 
Claude Lévi-Strauss sobre la diferenciación entre sociedades primitivas y sociedades modernas, entre culturas y civilizaciones (tal como las distinguen los antropólogos), que se basan en una identificación entre sociedades y culturas. A las culturas corresponderían sociedades «que crean poco desorden, lo que los físicos llaman 'entropía', y que tienen tendencia a mantenerse indefinidamente en su estado inicial, lo que explica, por otra parte, que se presenten como sociedades sin historia y sin progreso. Mientras que nuestras sociedades (las que corresponden a las civilizaciones modernas)... utilizan para su funcionamiento una diferencia de potencial que se encuentra realizada en diversas formas de jerarquía social... Son estas sociedades las que han llegado a provocar en su seno un desequilibrio social que emplean, por un lado, para producir mucho más orden -entre ellas están las sociedades del maquinismo-y, por otra parte, mucho más desorden, mucha menos entropía en el plano mismo de las relaciones humanas ${ }^{34}$. Las culturas primitivas, por lo tanto, serían producto de sociedades igualitarias en las que las relaciones entre los grupos están reglamentadas de una vez para siempre y se repiten invariablemente, mientras que las civilizaciones se fundarían sobre sociedades con relaciones jerarquizadas, con fuertes diferencias entre los grupos y, por lo tanto, serían objeto de cambios de tensiones, de conflictos sociales, de luchas políticas y de una perpetua evolución.

La señal exterior más importante de estas distinciones entre «culturas» $\mathrm{y}$ «civilizaciones» sería, sin duda alguna, a juicio de Braudel, la presencia o ausencia de ciudades. En este caso Braudel tampoco abre una vía original en su concepción de civilización, ya que esta relación civilización versus urbanidad ya había sido iniciada años antes por Gordon Childe en Man makes himself y en What happened in history, así como por Robert Redfield en Peasant society and culture ${ }^{35}$ : «Otro rasgo común a todas las

entonces debe incluirse en el activo de la alta burguesía parlamentaria, enfrentada con la Monarquía y defraudada por ella: su trágica suerte, el tomar conciencia de ello, su ascendencia intelectual le permiten poner una impronta al Gran Siglo francés, la suya.

${ }^{34}$ Citado por F. Braudel, Las civilizaciones actuales, op. cit., p. 28.

${ }^{35}$ Los dos obras de Childe están traducidas al castellano: Gordon Childe, Los orígenes de la civilización, México, Fondo de Cultura Económica, 1980 (Londres, 1936); Qué sucedió en la historia, Barcelona, Planeta-Agostini, 1985 (Londres, 1954). No sucede lo mismo con el libro de Robert Redfield, Peasant society and culture, Chicago, University of Chicago Press, 1956.

«CUADERNOS DE ESTUDIOS GALLEGOS», Tomo XLIX, Fascículo 115, Santiago 2002. 
ciudades y que, sin embargo, se encuentra en el origen de sus profundas diferencias de fisonomía, es que éstas son siempre producto de sus civilizaciones. Para cada una de ellas existe un prototipo ${ }^{36}$. Aunque toda ciudad se aparta «algo», por supuesto, de este esquema.

En el nivel de las civilizaciones, las ciudades proliferarían mientras que apenas están esbozadas en el nivel de las culturas. De todos modos, entre una categoría y otra hay jalones intermedios ${ }^{37}$. Sin embargo, las civilizaciones, las sociedades más flamantes, englobarían, dentro de sus propios límites, culturas y sociedades elementales. A este respecto, se refiere Braudel a la relación dialéctica entre las ciudades y el campo ${ }^{38}$. En una sociedad, el desarrollo nunca habría alcanzado por igual a todas las regiones, a todas las capas de la población: «Es frecuente que queden islotes de subdesarrollo (zonas montañosas demasiado pobres, o apartadas de las redes de comunicación), verdaderas sociedades primitivas, verdaderas 'culturas' en medio de una civilización» ${ }^{39}$.

Braudel consigue establecer una geografía diferencial a partir de esta relación dialéctica. El éxito principal de Occidente radicaría, en este sentido, en la captación, llevada a cabo por las ciudades, del campo, de sus «culturas» campesinas ${ }^{40}$. En el Islam, la dualidad habría permanecido más

${ }^{36} \mathrm{~F}$. Braudel, Civilización material, economía y capitalismo. Siglos XV-XVIII, Madrid, 1984 (París, 1979), I, p. 443. De esta manera, «no hay duda de que existe en todo el Islam, desde Gibraltar a las islas de la Sonda, un tipo de ciudad islámica y este único ejemplo puede bastarnos como expresión de las evidentes relaciones entre ciudades y civilizaciones», ibid.

${ }^{37}$ Así, por ejemplo, «el Africa negra está constituida por un grupo de sociedades tradicionales de culturas empeñadas en el proceso difícil y a veces cruel, de una civilización naciente y de una urbanización moderna. Sus ciudades, atentas a lo que viene de fuera, a lo que desemboca en la vida unitaria del mundo, son como islas en medio del estancamiento del resto del país. Anuncian la sociedad y la civilización futuras», F. Braudel, Las civilizaciones actuales, op. cit., p. 28.

${ }^{38}$ «Entre la ciudad y el campo hay, pues, una relación dialéctica, relación tan vieja como el mundo: es la relación de las civilizaciones superiores con las culturas inferiores», F. Braudel, Las civilizaciones actuales, op. cit., p. 135.

${ }^{39} \mathrm{Ibid}$.

${ }^{40}$ En este sentido, «Occidente ha sido desde bastante pronto una especie de lujo del mundo. Las ciudades alcanzaron una importancia que no se encuentra en ningún otro sitio. Configuraron la grandeza del reducido continente, pero este problema, aunque muy conocido, no es sencillo». Sin embargo, Braudel reconoce que precisar una superioridad es evocar una inferioridad, o la medida en relación a la cual se constituye dicha superio-

«CUADERNOS DE ESTUDIOS GALLEGOS», Tomo XLIX, Fascículo 115, Santiago 2002. 
sensible que en Occidente, las ciudades son instaladas más de prisa, se convierten antes en ciudades que en Europa, mientras que el campo conserva un mayor grado de nomadismo. En el Extremo Oriente, la desconexión campo-ciudad continuaría siendo reglamentaria: las culturas habrían permanecido muy al margen, viviendo de ellas mismas y por sí mismas. Intercalándose entre las ciudades más importantes, el campo viviría en una economía prácticamente cerrada, a veces salvaje.

Por otra parte, y dada la estrecha relación existente entre civilización y sociedad, cree Braudel conveniente plantearse en términos sociológicos la historia larga de las civilizaciones. Pero no se atreve a continuar por esa senda que pusiese lo más mínimo en cuestión el estatuto de la historia, y enseguida se coloca en una situación defensiva: «puesto que somos historiadores, no podemos confundir sociedades y civilizaciones $\rangle^{41}$. ¿En qué consiste, a juicio de Braudel, la diferencia? Por supuesto, en el plano de la duración, ya que la civilización comprendería, supondría espacios cronológicos bastante más amplios que una realidad social dada.

La larga duración y civilización son órdenes preferenciales en el método historiográfico de Fernand Braudel, pero requieren junto a ellos la clasificación suplementaria inherente a las sociedades, también omnipresentes: «Todo es orden social, lo cual, para un historiador o un sociólogo, no es más que una reflexión digna de Perogrullo. Pero las verdades banales tienen su peso. A lo largo de muchas páginas he hablado de ricos y pobres, de lujo y miseria, de las dos caras de la vida. Son verdades monótonas $\rangle^{42}$. Sin embargo, esto no es suficiente. Más que de sociedades (la palabra es muy vaga, según Braudel), habría que hablar de socioeconomías: «Marx tenía razón: ¿quién posee los medios de producción, la tierra, los barcos, las materias primas, los productos elaborados, así como los puestos dominantes?». Sigue siendo evidente, sin embargo,

ridad: «supone proceder, antes o después, a una confrontación difícil y decepcionante con el resto del mundo. Ya se trate de trajes, monedas, ciudades o capitalismo, es imposible, siguiendo a Max Weber, librarse de comparaciones, pues Europa se explica 'en relación con los otros continentes'», F. Braudel, Civilización material, economía y capitalismo. Siglos $X V$-XVIII, I, p. 446 (para ambas citas).

${ }^{41}$ F. Braudel, Las civilizaciones actuales, op. cit., p. 29.

${ }^{42} \mathrm{~F}$. Braudel, Civilización material, economía y capitalismo. Siglos XV-XVIII, I, p. 492.

«CUADERNOS DE ESTUDIOS GALLEGOS», Tomo XLIX, Fascículo 115, Santiago 2002. 
para Braudel, que estas dos coordenadas: sociedad y economía, no bastan por sí solas: «el Estado multiforme, causa y consecuencia a la vez, impone su presencia, trastorna las relaciones, las modela, voluntaria o involuntariamente, desempeña un papel, a menudo muy determinante, en esas arquitecturas que pueden reagruparse a través de una especie de tipología de las diversas socioeconomías del mundo, unas de esclavos, otras de siervos y señores, y otras de hombres de negocios y precapitalistas... El problema sigue siendo el de una clasificación, el de una jerarquía bien elaborada de las sociedades $)^{43}$.

Hasta tal punto es primordial en la obra de Braudel la búsqueda de la totalidad. Pero, ¿cómo se relacionan los distintos pisos de la casa de la historia que pretende construir Braudel? Desgraciadamente, no nos lo explica. Y es que es muy difícil, demasiado complicado: «el hecho de que tales problemas -el largo plazo, la civilización, la sociedad, la economía, el Estado, las jerarquías de valores 'sociales'- se impongan en ese plano de realidades modestas de la vida material, prueba por sí solo que la historia se presenta ya aquí con sus enigmas, sus dificultades... El hombre no se reduce nunca a un personaje que quepa en una simplificación aceptable... Apenas entendido en su aspecto más sencillo, el hombre se reafirma en su habitual complejidad» ${ }^{44}$.

Braudel nos ofrece, en cambio, otra de sus definiciones cómodas y ambiguas: «Me he acostumbrado a hablar de la sociedad como un conjunto de conjuntos, como la suma integral de todos los hechos que los historiadores abordamos en las diversas ramas de nuestra investigación. Esto supone tomar de los matemáticos un concepto muy cómodo del que ellos mismos desconfían. Y quizás emplear una gran palabra para subrayar una verdad trivial, a saber que todo lo que es, no puede ser más que social. Pero el interés de una definición consiste en que suministra una problemática previa, reglas para una primera observación. Si esta observación se facilita, en sus comienzos y su desarrollo, si hay después una clasificación aceptable de los hechos y a continuación se va más allá, la definición es útil y se justifica» ${ }^{45}$.

\footnotetext{
${ }^{43} \mathrm{Ibid}$.

${ }^{44}$ Op. cit., I, p. 493.

${ }^{45}$ Op. cit., II, p. 398.
}

«CUADERNOS DE ESTUDIOS GALLEGOS», Tomo XLIX, Fascículo 115, Santiago 2002. 
Después, esta globalidad debe dividirse prácticamente en conjuntos más restringidos, más accesibles a la observación. No hay historiador, no hay economista o sociólogo que no proceda a efectuar divisiones de este género, aunque todas sean, en primera instancia, artificiales, tanto la de Marx (infraestructura, superestructura) como la tripartición sobre la que Braudel ha construido su Civilización material, economía y capitalismo. Siempre se trataría de procedimientos de explicación, aunque reconoce Braudel que queda por saber si permiten o no una comprensión eficaz de los problemas importantes: «Es, pues, una división banal distinguir... en el interior de este gran conjunto que es la sociedad, varios conjuntos y de los mejor conocidos: lo económico, evidentemente, en buen lugar; la jerarquía social o el marco social (por no decir la sociedad que, para mí, es el conjunto de los conjuntos); lo político; lo cultural. Cada uno de estos conjuntos se descompone a su vez en subconjuntos, y así sucesivamente. En este esquema, la historia global (o mejor, globalizante, es decir con pretensiones de totalidad, que tiende a serlo, pero no puede serlo nunca de forma plena), es el estudio de al menos cuatro 'sistemas' en sí mismos; luego en sus relaciones, sus dependencias, sus procesiones, sus múltiples correlaciones, sin sacrificarse a priori las variables propias de cada grupo a las intervariables, y a la inversa $\iota^{46}$. Como propósito, es loable, pero lo que no puede hacer Braudel es llevar a la práctica sus objetivos: «El ideal imposible sería presentarlo todo sobre un plano y con un solo movimiento. La práctica recomendable es, al dividirlo, conservar el espíritu de una visión globalizante $»^{47}$.

En Europa la economía en rápido desarrollo habría adquirido a menudo preferencia sobre los demás sectores a partir de los siglos XI o XII, o con más seguridad aún a partir del siglo XVI; los ha obligado a definirse con relación a ella, y «nadie duda de que esta primacía que se afirma no sea una de las raíces de la modernidad precoz del estrecho continente» ${ }^{48}$. Pero sería en vano, a juicio de Braudel, pensar que, con anterioridad a estos siglos de despegue, la economía no contaba apenas como lo sería pensar que, frente a la fuerza ascendente de la economía, repleta de múl-

\footnotetext{
${ }^{46}$ Op. cit., II, p. 399.

${ }^{47}$ Ibid.

${ }^{48} \mathrm{Ibid}$.
} 
tiples mutaciones revolucionarias, los otros sectores, la sociedad entera, no hayan desempeñado su papel, constituido por aceleradores, más a menudo por barreras, contrafuertes y frenos que se han mantenido y han actuado durante siglos: «Toda sociedad está atravesada por corrientes, erizada de obstáculos, de supervivencias obstinadas que obstruyen los caminos, de estructuras lentas cuya permanencia es, a los ojos del historiador, la característica reveladora. Estas estructuras históricas son visibles, reveladoras, en cierto modo mensurables: su duración es medida ${ }^{49}$.

A menudo, los análisis sociológicos de Braudel traslucen una serie de ideas políticas conservadoras. Por ejemplo, cuando subraya la importancia histórica de las jerarquías sociales: «En singular o en plural, jerarquía social viene a designar el contenido banal, pero esencial, de la palabra sociedad, promovido aquí, para la comodidad de nuestra exposición, a un rango superior». Jerarquía se aplicaría por sí misma, sin demasiadas dificultades, a la historia entera de las sociedades de población densa: ninguna de esas sociedades se desarrolla en un plano horizontal, en un plano de igualdad. Todas están abiertamente jerarquizadas. No hay sociedad sin osamenta, sin estructura: «si se mira desde arriba el conjunto de la sociedad, no son estas subcategorías lo que salta primero a la vista, sino más bien la desigualdad fundamental que divide a la masa, desde la cumbre hasta la base, según la escala de la riqueza y del poder. Toda observación revela esta desigualdad visceral que es la ley continua de las sociedades. Como lo reconocen los sociólogos, es una ley estructural, sin excepción» ${ }^{50}$.

De hecho, y aunque Jean-Paul Sartre sea capaz de soñar con una sociedad donde la desigualdad desaparezca, donde no habría ya una dominación de un hombre sobre otro, ninguna sociedad del mundo actual habría renunciado, nos dice Braudel, todavía, a la tradición y al uso del privilegio. Para obtener esa renuncia, sería necesario derribar todas las jerarquías sociales, y no solamente las del dinero, ni solamente las del Estado, ni solamente los privilegios sociales, sino también el peso desmesurado del pasado y de la cultura. El ejemplo de los países socialistas probaría, según Braudel, que la desaparición de una sola jerarquía (la

\footnotetext{
${ }^{49} \mathrm{Ibid}$.

${ }^{50}$ Op. cit., II, p. 404. Los ejemplos son numerosísimos a lo largo de la obra de F. Braudel.
}

«CUADERNOS DE ESTUDIOS GALLEGOS», Tomo XLIX, Fascículo 115, Santiago 2002. 
económica) plantea montañas de dificultades y no bastaría para establecer la igualdad, la libertad, ni siquiera la abundancia: «Una revolución lúcida -pero, ¿puede haberla? y si la hubiese, las circunstancias, siempre tan pesadas, ¿le permitirían conservar por mucho tiempo semejante privilegio? - tal revolución, hallaría muchas dificultades para demoler todo lo que es necesario demoler y conservar lo que importase conservar: una libertad básica, una cultura independiente, una economía de mercado sin artimañas, más un poco de fraternidad. Es mucho pedir» ${ }^{51}$. La metáfora de la escalera le sirve a Braudel para sintetizar una situación social jerarquizada. Es más, «sea lo que fuere lo que nos prometa el futuro, siempre encontraremos la permanencia de la escalera, la afirmación de la jerarquía» $^{52}$.

¿Que solución nos propone, sobre todo ahora, que estamos en tiempos de crisis? En primer lugar, paciencia: «ningún gobierno es el responsable de la crisis, como tampoco somos responsables de las depresiones de los ciclones que atraviesan, una tras otra, el Mediterráneo invernal. Predicaría paciencia, afirmaría que no hay remedio milagroso que proponer $\rangle^{53}$. Es decir, nada de revoluciones, nada de protestas. Y luego, apuesta por el egoísmo individualista, que, por supuesto, no importa que se refiera a una lucha desigual (al ser, evidentemente, desigual el punto de partida): «Hay que esperar, volver la espalda, adaptarse al mal tiempo, tratar individualmente de labrarse el propio camino. En beneficio de todos, porque la experiencia del pasado dice que, en tiempos de crisis, el individuo, el grupo pequeño, se manifiestan a menudo más inventivos que las pesadas unidades de la economía, o de la sociedad $»^{54}$. El hombre de Braudel es sumamente egoísta. La sociedad de Braudel termina por legitimar la desigualdad social. Las civilizaciones de Braudel se mantienen, y tienen su razón de ser, en la dinámica del enfrentamiento, y debemos estar preparados para la lucha «porque no se florece, no se es brillante, sino a condición de explotar a los demás $)^{55}$. En esta lucha hay que estar muy activos porque «explotamos, nos enriquecemos, dormimos, tenemos la necesidad

${ }^{51}$ Op. cit., III, p. 530.

${ }^{52}$ F. Braudel, Escritos sobre la historia, op. cit., p. 134.

${ }^{53}$ Op. cit., p. 128.

${ }^{54}$ Ibid.

${ }^{55}$ F. Braudel, Una lección de historia de Fernand Braudel, op. cit., p. 68. 
de ser servidos por los demás, y, en un momento dado, somos despedazados por los demás $\rangle^{56}$.

\section{TERCER DIÁLOGO: HISTORIA ADVERSUS ECONOMÍA}

En el concierto de la historia braudeliana, también la economía desempeñó un papel a menudo determinante. La sociedad no sería nada sin la explotación que la equilibra, y sin ella los estados serían cuerpos inertes. Por lo demás, si las civilizaciones duran y florecen, sería gracias a ella: «Las floraciones son gastos, despilfarros. Apenas surgen crisis económicas un poco serias, y la cantería de Santa Maria del Fiore en Florencia detiene sus trabajos, y la catedral de Bolonia o la de Siena quedan para siempre inconclusas ${ }^{57}$.

$\mathrm{Y}$ es que el concepto de civilización braudeliano es, en efecto, por lo menos doble. Se refiere tanto a los valores morales como a los materiales. Karl Marx distinguió las infraestructuras (materiales) de las superestructuras (espirituales), éstas en estrecha dependencia de aquéllas. Charles Seignobos decía que «la civilización consiste en las carreteras, en los puertos y en los muelles», lo que es una manera de decir que al hablar de civilización no se trata únicamente del espíritu. Marcel Mauss definió la civilización "como todo lo adquirido por el hombre», y el historiador Eugène Cavaignac ha dicho: «Es un mínimo de ciencia, de arte, de orden y de virtudes...». Por lo tanto, la civilización se daría, como mínimo, en dos niveles, lo que explicaría, a juicio de Braudel, que muchos autores no hayan reparado en distinguir entre cultura y civilización, cargando al primer término con la dignidad de lo espiritual y al segundo con la trivialidad de lo material ${ }^{58}$.

\footnotetext{
${ }^{56}$ Op. cit., p. 69.

${ }^{57} \mathrm{~F}$. Braudel, El Mediterráneo. El espacio y la historia, op. cit., p. 159.

${ }^{58}$ «Es, en efecto, utópico pretender, a la manera alemana, aislar a la cultura de su base, que estaría constituida por la civilización. Tan absurdo es tratar con negligencia a la superestructura como a la infraestructura, cosa que tantas veces se ha hecho. Las civilizaciones tienen los pies en el suelo. Para arriesgar una fórmula rápida, nos es necesario, valga lo que valga, obligar a marchar con un mismo paso tanto a Toynbee o a Lucien Febvre, por un lado, como, por otro, a los sociólogos, a los antropólogos, a los economistas, a los mismos marxistas. ¿Qué tremenda puerilidad el desdén manifestado hacia
} 
De manera que toda sociedad, toda civilización estaría condicionada por unos datos económicos, técnicos, biológicos, demográficos: «Las condiciones materiales y biológicas son siempre un factor importante en el destino de las civilizaciones. El aumento o la disminución de la población, la salud o la decrepitud físicas, el auge o la decadencia económica o técnica repercuten tanto en el edificio cultural como en el social» ${ }^{59}$.

En este saco que significa, para Braudel, la economía, incluye a la demografía ${ }^{60}$, de manera que privilegia la importancia del número de hombres: «durante mucho tiempo el hombre fue el único instrumento, el único motor al servicio del hombre, por consiguiente el único artesano de la civilización material. Ha construido esta civilización con la fuerza de sus brazos y de sus manos $\rangle^{61}$. En principio, toda expansión geográfica habría favorecido el auge de las civilizaciones. Así ocurrió en Europa en los siglos XIII, XVI, XVIII y en los siglos XIX y XX. Regularmente también, la excesiva abundancia de hombres, beneficiosa en un principio, un día se volvería nociva, cuando el aumento de la población excede al crecimiento económico. Esto sería, probablemente, lo que ocurrió en Europa, antes de terminar el siglo XVI. Y lo mismo ocurriría en la actualidad en la mayoría de los países subdesarrollados. En el mundo entero se habrían producido, en consecuencia, períodos de hambre, disminución del salario real, revueltas populares, épocas siniestras de retroceso. Hasta el momento en el que las epidemias venían a sumarse al hambre, clareando así las filas demasiado densas de hombres. Después de estas catástrofes biológicas (como por ejemplo, la de la segunda mitad del siglo XIV europeo, con la peste negra y las epidemias subsiguientes, o la que se precisa en el siglo XVIII), los supervivientes vivirían de momento con más soltu-

\footnotetext{
Marx en todo este descarrío idealista a que la mayoría de las veces se reduce el estudio de las civilizaciones!», F. Braudel, «Aportación de la historia de la civilización», La historia y las ciencias sociales, op. cit., p. 180.

${ }^{59}$ F. Braudel, Las civilizaciones actuales, op. cit., p. 29.

${ }^{60}$ «Se impone un diálogo del mismo tipo con los demógrafos: la civilización es hija del número. ¿Cómo es posible que Toynbee no se preocupe de ello más que accidentalmente? Un empuje demográfico puede provocar, y de hecho provoca, rupturas, mutaciones. Una civilización está por debajo o por encima de su carga normal de hombres. Todo rebasamiento tiende a producir esas amplias e insistentes migraciones», en: F. Braudel, «Aportación de la historia de la civilización», La Historia y las ciencias sociales, op. cit., pp. 180-181.

${ }^{61}$ F. Braudel, Las civilizaciones actuales, op. cit., p. 29.
} 
ra y el movimiento de expansión volvería a empezar y a acelerarse hasta un nuevo frenazo.

Sin embargo, la industrialización habría roto, a finales del siglo XVIII, y en el siglo XIX, este círculo vicioso y que habría devuelto al hombre, incluso en casos de superpoblación, su valor y la posibilidad de trabajar y de vivir. Así lo demostraría la historia de Europa: este valor creciente del hombre, planteándose la necesidad de economizar sobre su empleo, habría determinado el auge de las maquinas y de los motores ${ }^{62}$.

En el primer tomo de su Civilización material, economía y capitalismo, Braudel consigue elaborar un modelo a partir de las densidades de poblamiento y los niveles de civilización. Para lograrlo, realizó una serie de cálculos: teniendo en cuenta que la superficie de las tierras emergidas es de 150 millones de $\mathrm{km}^{2}$, la densidad media del globo, con sus 4.000 millones de hombres, es de 26,7 habitantes por $\mathrm{km}^{2}$ (1979). El mismo cálculo, entre 1300 y 1800 , daría la cifra mínima de 2,3 habitantes por $\mathrm{km}^{2}, \mathrm{y}$ la máxima de 6,6. Calcula después la superficie actual de las zonas más pobladas (200 habitantes y más por $\mathrm{km}^{2}$ )y obtiene, de este modo, la superficie fundamental de las civilizaciones densas de hoy, es decir, 11 millones $\mathrm{de}_{\mathrm{km}}^{2}$. En esta estrecha banda se concentra el $70 \%$ de los seres vivos (casi 3.000 millones de hombres): «El hombre deja vacías las nueve décimas partes del globo, a menudo a la fuerza, por negligencia también y porque la historia, interminable cadena de esfuerzos, así lo ha decidido» ${ }^{63}$. En su

\footnotetext{
${ }^{62}$ «A pesar de su alto nivel intelectual la antigüedad greco-romana no contó con las máquinas adecuadas a su inteligencia. En realidad, no hizo ningún intento serio para conseguirlas, puesto que, en sustitución, tenía esclavos. La China clásica, constituida mucho antes del siglo XII, tan inteligente ella también y en particular en lo que se refiere a las técnicas, tuvo, desgraciadamente, una superabundancia de hombres. El hombre no cuesta nada; realiza cualquier tarea con la mayor economía, mayor incluso que la del animal doméstico...». En consecuencia, China, que durante largo tiempo habría sido progresiva en el plano científico, no franquearía el umbral de la ciencia moderna. A Europa le correspondería, según Braudel, este privilegio, este beneficio. F. Braudel, Las civilizaciones actuales, op. cit., p. 30.

${ }^{63} \mathrm{~F}$. Braudel, Civilización material, economía y capitalismo. Siglos XV-XVIII, I, p. 32. Recoge, particularmente, la siguiente cita de Vidal de la Blache: «Los hombres no se han extendido sobre la tierra como una mancha de aceite, se han agrupado primitivamente como los corales, es decir, superponiéndose en «capas sucesivas» sobre «ciertos puntos de los bancos de poblaciones humanas»"), P. Vidal de la Blache, Principes de géographie humaine, 1922, pp. 10-11.
}

«CUADERNOS DE ESTUDIOS GALLEGOS», Tomo XLIX, Fascículo 115, Santiago 2002. 
primer momento se tendería a pensar, por la gran debilidad de las densidades, que no existieron en ninguna parte, entre 1400 y 1800 , esas humanidades verdaderamente densas que crean civilizaciones. Sin embargo, de hecho, la misma separación, la misma asimetría divide al mundo entre zonas muy pobladas y zonas amplias y vacías, con pocos hombres. Una vez más se impone, a juicio de Braudel, interpretar las cifras a su escala.

Conocemos el emplazamiento aproximadamente exacto de las civilizaciones, de las culturas evolucionadas, de las culturas primitivas en todo el mundo, asegura Braudel, hacia 1500, gracias a los documentos de la época, los relatos posteriores y las investigaciones de los etnógrafos. E1 mapa del universo, hacia el año 1500, elaborado por un etnógrafo, Gordon W. Hewes ${ }^{64}$, que Braudel reproduce, distingue 76 pequeñas casillas de formas y de superficies diversas, que se reparten los 150 millones de $\mathrm{km}^{2}$ de tierras emergidas. Estas 76 piezas del puzzle esbozan una clasificación desde la casilla número 1, la de Tasmania, hasta la número 76 y última, la de Japón. La clasificación se lee de abajo a arriba: en primer lugar, del número 1 al número 27 están ordenados los pueblos primitivos, recolectores, pescadores; en segundo lugar, del número 28 al número 44 , los nómadas y ganaderos; en tercer lugar, del número 45 al número 63 , los pueblos de agricultura todavía deficiente, ante todo los campesinos de azada; y por último, del número 64 al número 76, «las civilizaciones, poblaciones relativamente densas, en posesión de múltiples medios y ventajas: animales domésticos, arados, la tracción sobre ruedas, y sobre todo las ciudades... $\nu^{65}$. Es inútil insistir, opina Braudel, en que son precisamente estas 13 últimas las que forman los países «desarrollados», el universo denso de los hombres.

Discute nuestro autor esta clasificación en algunos puntos: «¿Habría que colocar con pleno derecho, en este lugar, los números 61 y 62 , es decir, la civilización azteca o mexicana, y la civilización inca o peruana? Es evidente que sí, si se trata de su calidad, de su brillantez, de sus artes, de sus mentalidades originales; la respuesta también será afirmativa si se consideran las maravillas de cálculo de los antiguos mayas; sí de nuevo si

${ }^{64}$ Este estudio había sido publicado bajo el título «A Conspectus of the World's Cultures in 1500 A.D.», en: University of Colorado Studies, $\mathrm{n}^{\circ} 4$, 1954, pp. 1-22.

${ }^{65} \mathrm{~F}$. Braudel, Civilización material, economía y capitalismo. Siglos XV-XVIII, I, p. 33.

«CUADERNOS DE ESTUDIOS GALLEGOS», Tomo XLIX, Fascículo 115, Santiago 2002. 
se piensa en su longevidad: sobrevivieron al espantoso choque de la conquista de los blancos. Habría que contestar, por el contrario, que no, si se constata que no utilizaban más que la azada y el bastón cavador; que no conocían (salvo la llama, la alpaca y la vicuña) ningún animal doméstico grande; que ignoraban la rueda, la bóveda, el carro, la metalurgia del hierro, esta última conocida desde hacía siglos, e incluso milenios, por las culturas, sin embargo, modestas del África negra. En suma, es evidente que la respuesta es negativa, de acuerdo con nuestros criterios de la vida material. Surgen la misma vacilación y la misma reticencia en lo que se refiere a la casilla 63, es decir al grupo finlandés, que apenas comienza entonces a dejarse influir por las civilizaciones vecinas» ${ }^{66}$.

Las 13 civilizaciones restantes forman, a escala mundial, una larga y estrecha franja en el conjunto del Viejo Mundo: «Allí donde el hombre civilizado se encontraba en 1500 , se encontraba ya en 1400 , y se encontrará en $1800 \mathrm{y}$ aún hoy» ${ }^{67}$. Se hace el balance rápidamente: Japón, Corea, China, Indochina, Insulindia, la India, el Islam filiforme, las cuatro diferentes Europas (la latinidad mediterránea, la griega, la nórdica y la rusolapona), las civilizaciones del Cáucaso y civilización abisinia.

Con esto tenemos, en total, unos 10 millones de $\mathrm{km}^{2}$, un espacio mínimo, un huso de altas densidades individualizado, reconocible, mutatis mutandis, en la geografía actual del mundo (donde sobre un total de 11 millones de $\mathrm{km}^{2}$ vive el $70 \%$ de los hombres). Si aceptáramos esta proporción actual de la masa humana, nos dice Braudel, de las civilizaciones con relación al conjunto ( $70 \%$ del total), la densidad kilométrica de estas zonas privilegiadas ascendería, entre 1300 y 1800 , teniendo en cuenta nuestros puntos de referencia extremos, de 24,5 (mínimo) a 63,6 (máximo). En 1600, nuestra medida se situaría entre 28 y $35 \%$. Es decir, un umbral importante: si el poderío de Europa exige entonces por lo menos 17 millones de habitantes, en el mundo, el umbral de concentración por encima del cual vive y prospera una civilización, es de unos treinta habitantes por $\mathrm{km}^{2}$. A esta dudosa, cuando menos, conclusión, llega Braudel, con la cual ya tiene vía libre para esbozar una geografía diferencial más «objetiva», de manera que sólo los Países Bajos y Francia superan ese

\footnotetext{
${ }^{66}$ Op. cit., I, p. 33.

${ }^{67}$ Ibid.
}

«CUADERNOS DE ESTUDIOS GALLEGOS», Tomo XLIX, Fascículo 115, Santiago 2002. 
umbral de civilización: «En 1600, la populosa Italia tenía 44 habitantes por $\mathrm{km}^{2}$; los Países Bajos, 40; Francia, 34; Alemania, 28; la Península Ibérica, 17; Polonia y Prusia, 14; Suecia, Noruega y Finlandia, alrededor de 1,5 (pero víctimas de una Edad Media primitiva y prolongada, se encontraban marginadas respecto a Europa, y no participaban en la vida de ésta más que a través de exiguas regiones de su territorio). En cuanto a China, la China de las 17 provincias (la $18^{\mathrm{a}}$, el Kansu, pertenecía entonces al Turquestán chino), tenía una densidad apenas superior a $20(1578)\rangle^{68}$.

Braudel extrae otras sugerencias del mapa de Gordon W. Hewes: a saber, «la gran estabilidad del asentamiento de las 'culturas' (primeros éxitos) y de las 'civilizaciones' (segundos éxitos de los hombres)» ${ }^{69}$; la puesta en relieve de que, antes del triunfo de Europa, el mundo entero había sido aprehendido por el hombre desde hacía siglos o milenios (la humanidad sólo se habría detenido ante los obstáculos mayores: las inmensidades marinas, las montañas, las masas forestales, los desiertos); y, última observación, las estrechas zonas de población densa no habrían sido siempre homogéneas, ya que al lado de regiones sólidamente ocupadas (Europa occidental, Japón, Corea, China) habría otras de población muy dispersa.

Diálogo también con la estadística: «Que me perdone Lucien Febvre el declararme a favor de Alfredo Nicéforo, incluso si sus índices constituyen unas malas medidas de civilizaciones: no existen las medidas perfectas. Me declaro también a favor de las 'aproximaciones' de Georges Gurvitch respecto de las 'sociedades globales', ese cuerpo -si tengo derecho a emplear a mi vez el término- de las civilizaciones. Y aunque estas 'aproximaciones' continúen siendo demasiado tímidas para mi gusto, parecen ya cercar lo real si se las compara con e alegre idealismo de P. Sorokin $»^{70}$. Además, se debería reemprender un debate para decidir las relaciones que median entre civilizaciones y estructuras o clases sociales:

\footnotetext{
${ }^{68}$ Op. cit., I, p. 36.

${ }^{69}$ Puesto que estos asentamientos han sido reconstruidos a partir del tiempo presente por un simple método regresivo. Sus límites se han mantenido. «Su ensamblaje es pues un rasgo geográfico tan fuerte como los Alpes, el Gulf Stream o el trazado del Rin». F. Braudel, Civilización material, economía y capitalismo. Siglos XV-XVIII, I, pp. 37-38.

${ }^{70} \mathrm{~F}$. Braudel, «Aportación de la historia de las civilizaciones», en: La Historia y las ciencias sociales, op. cit., p. 181-182.
} 
«Sostengo, por último que no existe civilización sin un sólido andamiaje económico, social y político, que determina, por lo demás, su vida moral e intelectual (en el buen o en el mal sentido) y hasta su vida religiosa» ${ }^{71}$.

Un factor de gran influencia en el desarrollo de civilización braudeliana es la incidencia de las fluctuaciones económicas en la vida real de las civilizaciones. De hecho, la vida económica estaría continuamente oscilando en fluctuaciones, las unas cortas, las otras largas: «Así se suceden, a lo largo de los años, los momentos de buen tiempo y de mal tiempo económicos, $\mathrm{y}$, en cada caso, las sociedades y las civilizaciones acusan las consecuencias, sobre todo cuando se trata de movimientos prolongados» ${ }^{72}$. De este modo, el pesimismo y la inquietud del final del siglo XV corresponderían a un claro repliegue de la economía de Occidente ${ }^{73}$. Igualmente, más tarde, el Romanticismo europeo coincidiría con un retroceso económico de larga duración, entre 1817 y 1852. Las expansiones económicas de la segunda parte del siglo XVIII (a partir de 1733) serían objeto de algunos frenazos (como el que precedió a la Revolución Francesa), pero, en su conjunto, su aceleración situaría el auge intelectual del «Siglo de las Luces» en un contexto de bienestar, de comercio activo, de expansión industrial y de aumento de la población.

Por otra parte, la vida económica sería casi siempre creadora de excedentes, sea cual sea el sentido de la fluctuación. Ahora bien, el gasto, el despilfarro de estos excedentes han sido una de las condiciones indispensables para el lujo de las civilizaciones, para ciertas formas del arte: «Al admirar, hoy en día, esta arquitectura, aquella escultura o aquel retrato,

\footnotetext{
${ }^{71}$ Op. cit., p. 181.

${ }^{72} \mathrm{~F}$. Braudel, Las civilizaciones actuales, op. cit., p. 30.

${ }^{73}$ «No es exactamente esto lo que ha hecho J. Huizinga, en un libro célebre y sin duda magnífico sobre el fin, el 'otoño' de la Edad Media occidental, una 'agonía' de la civilización, como dijo más tarde. De hecho, la agonía -si agonía hubiere- no sería irremediable: personalmente, me parece una etapa, un nombre de la civilización occidental. Pero lo que más reprocho a Huizinga es haber mantenido la mirada tan arriba, hasta el punto de no considerar obstinadamente más que el último piso del espectáculo, lo alto de la hoguera. Es una desgracia que no haya podido disponer de los estudios demográficos y económicos, hoy día clásicos, sobre el poderoso retroceso de Occidente en el siglo XV: le habrían proporcionado los cimientos que le faltan a su libro. Porque, insisto en ello, los grandes sentimientos, por lo demás tanto los más elevados como los más bajos, nunca pueden tener una vida independiente», F. Braudel, «Aportación de la historia de la civilización», en: La Historia y las ciencias sociales, op. cit., pp. 183-184.
}

«CUADERNOS DE ESTUDIOS GALLEGOS», Tomo XLIX, Fascículo 115, Santiago 2002. 
contemplamos también, sin ser siempre conscientes de ello, el tranquilo orgullo de una ciudad, o la vanidosa locura de un príncipe, o la riqueza recién estrenada de un comerciante banquero» ${ }^{74}$. En Europa, desde el siglo XVI (y probablemente desde antes), la civilización en su último grado estaría bajo el signo del dinero y del capitalismo.

La civilización se encontraría así en función de una cierta redistribución del dinero: «Las civilizaciones se particularizan en su cumbre y, más tarde, en su masa, según el mecanismo de redistribución que les es propio, según los mecanismos sociales y económicos que reserva en los circuitos del dinero la parte destinada al lujo, al arte, a la cultura. En el siglo XVII, en los años económicamente muy duros del reinado de Luis XIV, en la Corte no hay más que mecenas. Toda la vida literaria y artística se centra en este estrecho círculo. Con la riqueza y las facilidades económicas del siglo XVIII, tanto la aristocracia como la burguesía, toman parte activa, al lado de la Monarquía, en la difusión de la cultura, de la ciencia, de la filosofía.... $\rangle^{75}$.

Pero, en esta época, el lujo continuaría siendo el privilegio de una minoría social. La civilización subyacente, la de la vida cotidiana y pobre no tendría participación alguna. Ahora bien, «la capa más baja de una civilización es la que determina su grado de verdad. ¿Qué es, entonces, la libertad? ¿Qué es la cultura del individuo, cuando un mínimo vital está fuera de su alcance?» ${ }^{76}$. Desde este punto de vista, a juicio de Braudel, el tan denigrado siglo XIX europeo, el siglo XIX de los nuevos ricos y del «empuje burgués», el tan aburrido siglo XIX sería el que anuncie ya, aunque no lo realice aún, un nuevo destino para las civilizaciones y para la persona humana. Al tiempo que aumenta el número de hombres, éstos empezarían, cada vez en un número mayor, a participar en una cierta civilización colectiva: «Sin ninguna duda, el precio de semejante transformación -que, por otra parte, fue inconsciente- ha sido, socialmente, muy gravoso. Pero se ve contrarrestado con creces: el desarrollo de la enseñanza, el acceso a la cultura, a las Universidades, la movilidad social, son conquistas, ricas en consecuencias, del ya rico siglo XIX»» ${ }^{77}$.

\footnotetext{
${ }^{74} \mathrm{~F}$. Braudel, Las civilizaciones actuales, op. cit., pp. 30-31.

${ }^{75}$ Op. cit., p. 31.

${ }^{76}$ Ibid.

${ }^{77} \mathrm{Ibid}$.
} 
Tanto en la actualidad como en el futuro, el problema estaría en crear una civilización que fuese al mismo tiempo cualitativamente rica y civilización de masas, tremendamente cara, inconcebible, nos dice Braudel, si no se pone una cantidad importante de excedentes al servicio de la sociedad, inconcebible, también, sin los momentos de ocio que el maquinismo puede y debe proporcionar: «En los países industrializados, este futuro está previsto para un plazo de tiempo relativamente corto. Pero el problema es mucho más complejo a escala mundial. Porque las desigualdades en el acceso a la civilización que la vida económica ha hecho surgir entre las diferentes clases sociales, también las ha creado entre los diversos países del mundo» ${ }^{78}$. Una gran parte de éste constituiría lo que Toynbee calificó de «proletariado exterior», lo que comúnmente se llama Tercer Mundo, portador de una inmensa masa de hombres para quienes el acceso a un mínimo vital se plantea bastante antes que el acceso a la civilización de su propio país.

Introducimos en este momento en nuestro estudio el análisis de la economia-mundo, otra de las expresiones de Fernand Braudel que obtuvieron un gran éxito dentro del campo del conocimiento histórico, sobre todo en la historiografía francesa de la años sesenta. El espacio como fuente de explicación hace intervenir otra vez a todas las «realidades» de la historia, todas las partes importantes de la extensión: los Estados, las sociedades, las culturas, las economías... Y, según se elija uno u otro de estos conjuntos, la significación y el papel del espacio se modifican: «La economía-mundo (expresión inesperada y poco oportuna a nuestra lengua que forjé antaño, a falta de otra mejor y sin demasiada lógica, para traducir un uso particular de la palabra alemana Weltwirtschaft) sólo se refiere a un fragmento del universo, a un trozo del planeta económicamente autónomo, capaz en lo esencial de bastarse a sí mismo y al cual sus vínculos e intercambios interiores confieren cierta unidad orgánica» ${ }^{79}$. De manera que una economía-mundo sería una suma de espacios individuales, económicos y no económicos, reagrupados por ella; que abarcaría una superficie enorme (en principio, es la más vasta zona de coherencia,

\footnotetext{
${ }^{78}$ Ibid.

${ }^{79} \mathrm{~F}$. Braudel, Civilización material, economía y capitalismo. Siglos XV-XVIII, III, p. 6.
}

«CUADERNOS DE ESTUDIOS GALLEGOS», Tomo XLIX, Fascículo 115, Santiago 2002. 
en tal o cual época, en una parte determinada del globo); que traspasaría, de ordinario, los límites de los otros agrupamientos masivos de la historia. Además, siempre habría habido economías-mundo, lo mismo que desde siempre hubo sociedades, civilizaciones, Estados e Imperios.

El tiempo vivido nos propone, a juicio de Braudel, una serie de ejemplos de economías-mundo. No serían muy numerosos, pero suficientes para permitir las comparaciones. Además, como cada economía-mundo ha sido de larga duración, habría evolucionado, se habría transformado en el lugar con respecto a sí misma y a sus épocas; sus estados sucesivos también sugerirían comparaciones. La materia sería bastante rica para autorizar una especie de tipología de las economías-mundo.

La primera tarea para explicar cualquier economía-mundo consiste en delimitar el espacio que ocupa. Por lo común, sus límites son fáciles de establecer porque se modifican lentamente. La zona que engloba se presenta como la primera condición de su existencia. No hay economía-mundo que no tenga un espacio propio. Ya tenemos la primera regla: «un espacio que varía lentamente» ${ }^{80}$. Los límites de una economía-mundo se situarían allí donde comienza otra economía del mismo tipo, a lo largo de una zona que, tanto de un lado como del otro, no es ventajoso atravesar, económicamente hablando, más que en casos excepcionales. Sería conveniente tomar, una vez más, la medida de esas distancias hostiles. Se necesita vencer el espacio para dominarlo, y el espacio no cesaría de vengarse, imponiendo la reanudación de sus esfuerzos. Por otra parte, propone Braudel una «segunda regla: el centro, una ciudad dominante» ${ }^{81}$. En efecto, las primacías urbanas se suceden de modo que las ciudades dominantes no lo son in ceternum: se reemplazan. La tercera regla, por su parte, se refiere a que las diversas zonas están jerarquizadas. Las diversas zonas de una economía-mundo miran hacia un mismo punto, el centro: «polarizadas», forman ya un conjunto de múltiples coherencias: «Toda economíamundo es un encaje, una yuxtaposición, de zonas ligadas unas con otras, pero a niveles diferentes. En concreto, se delinean, al menos, tres 'áreas', tres categorías: un centro estrecho, regiones segundas bastante desarrolladas y, por último, enormes márgenes exteriores. Y, necesariamente, las

\footnotetext{
${ }^{80}$ Op. cit., III, p. 10.

${ }^{81}$ Op. cit., III, p. 11.
} 
cualidades y características de la sociedad, la economía, la técnica, la cultura y el orden político cambian según nos desplazamos de una zona a otra ${ }^{82}$. Sin embargo, las zonas atrasadas no estarían distribuidas exclusivamente en las verdaderas periferias. En realidad, salpican las mismas regiones centrales con múltiples manchas regionales. Así, todas las economías avanzadas estarían como perforadas por innumerables pozos fuera del tiempo del mundo: «Esta es una forma indirecta de hablar de regiones que hoy llamaríamos 'subdesarrolladas', donde la vida sigue su estilo tradicional, donde sus campesinos tienen a su disposición los recursos de una caza abundante, de salmones y truchas que pululan en los ríos. En cuanto a los hombres, habría que hablar de salvajismo... Estos hombres primitivos lucharán ferozmente para preservar su vida, atacando a los ingenieros y a los terraplenadores, destruyendo los diques y asesinando a los obreros malditos. Tales conflictos, de la modernización contra el arcaísmo, se producen todavía ante nuestros ojos... No obstante, estas violencias son relativamente raras. Por lo general, la 'civilización', cuando lo necesita, tiene mil medios para seducir a, y penetrar en, las regiones que antes había abandonado durante largo tiempo a sí mismas. Pero, ¿es $\tan$ diferente el resultado?» ${ }^{83}$.

Pero, ¿qué relación existe entre el concepto de economía-mundo y el de civilización? Nos lo explica Braudel en el epígrafe «El orden cultural» de su Civilización material, economía y capitalismo: «Las culturas (o las civilizaciones, pues ambas palabras pueden emplearse una en lugar de otra, en la mayoría de los casos) son también un orden organizador del espacio, tanto como las economías. Si bien aquéllas coinciden con éstas (en particular, porque el conjunto de una economía-mundo, en toda su extensión, tiende a compartir una misma cultura, o al menos ciertos elementos de una misma cultura, en oposición a las economías-mundo vecinas), también se diferencian de ellas: los mapas culturales y los mapas económicos no se superponen sin más, y esto es bastante lógico, aunque sólo sea por el hecho de que la cultura procede de una interminable duración que supera, con mucho, la longevidad, sin embargo impresionante,

${ }^{82}$ Op. cit., III, p. 22.

${ }^{83}$ Op. cit., III, p. 25. Utiliza aquí Braudel una concepción evolucionista de civilización, en el sentido de ideal a alcanzar, por una parte, y de etapa en la que las diferencias no serían de esencia sino de grado de evolución o de progreso.

«CUADERNOS DE ESTUDIOS GALLEGOS», Tomo XLIX, Fascículo 115, Santiago 2002. 
de las economías-mundo ${ }^{84}$. La civilización, por tanto, sería el personaje más antiguo de la historia de los hombres: las economías se reemplazan, las instituciones políticas se rompen y las sociedades se suceden, pero la civilización continúa su camino ${ }^{85}$.

En el corazón de toda civilización, se afirmarían los valores religiosos. Es una realidad que vendría de muy lejos. Si la Iglesia, en la Edad Media y más tarde, lucha contra la usura y el advenimiento del dinero, es, a juicio de Braudel, porque representa a una época pasada, muy anterior al capitalismo, que no soporta las novedades: «Pero la realidad religiosa no es por sí sola la cultura entera; ésta también es espíritu, estilo de vida, en todos los sentidos de la expresión, literatura, arte, ideología, tomas de conciencia, etc. La cultura está hecha de una multitud de bienes, materiales y espirituales» ${ }^{86}$.

Y para que todo sea más complicado aún, ella sería, a un tiempo, sociedad, política y expansión económica. Lo que la sociedad no logra, la cultura lo consigue; la cultura limita la posibilidad de lo que la economía haría por sí misma, y así sucesivamente. Además, no hay ningún límite cultural reconocible que no sea la prueba de una multitud de procesos ocurridos ${ }^{87}$. Forzosamente, una civilización-mundo y una economía-mundo pueden unirse y hasta apoyarse mutuamente: «La conquista del Nuevo

\footnotetext{
${ }^{84}$ Op. cit., III, p. 45.

${ }^{85}$ Así, por ejemplo, «Roma se derrumba en el siglo V después de Jesucristo, pero la Iglesia Romana la continúa hasta nuestros días. El hinduismo, al erguirse contra el Islam en el siglo XVIII, abre un abismo por donde se desliza la conquista inglesa, pero la lucha entre las dos civilizaciones sigue ante nuestros ojos, con todas sus consecuencias, mientras el Imperio Inglés de la India ya no existe desde hace un tercio de siglo. La civilización es el anciano, el patriarca, de la historia del mundo». F. Braudel, Civilización material, economía y capitalismo. Siglos XV-XVIII, III, p. 45.

${ }^{86} \mathrm{Ibid}$.

${ }^{87}$ «La frontera del Rin y del Danubio es una frontera cultural por excelencia: de un lado, la vieja Europa cristiana, del otro, una 'periferia cristiana', conquistada en época más reciente. Ahora bien, cuando surge la Reforma, es... la línea de ruptura a lo largo de la cual se estabiliza la desunión cristiana: protestantes de un lado, católicos del otro. Y es también, evidentemente, el antiguo límite, el limes del Imperio Romano. Muchos otros ejemplos nos hablarían de un lenguaje análogo, aunque no sea más que la expansión del arte románico y del arte gótico, que, uno y otro, confirmando la regla las excepciones, dan testimonio de una creciente unidad cultural de Occidente: es, en verdad, una culturamundo, una civilización-mundo». F. Braudel, Civilización material, economía y capitalismo. Siglos XV-XVIII, III, pp. 45-46.
}

«CUADERNOS DE ESTUDIOS GALLEGOS», Tomo XLIX, Fascículo 115, Santiago 2002. 
Mundo fue también la expansión de la civilización europea en todas sus formas, y esta expansión sostuvo y protegió la expansión colonial. En la misma Europa, la unidad cultural favorece los intercambios económicos, y recíprocamente. La aparición del gótico en Italia, en la ciudad de Siena, fue una importación directa de los grandes mercaderes sieneses que frecuentaban las ferias de Champaña» ${ }^{88}$. Así, la letra de cambio circula casi exclusivamente en los límites de la cristiandad, todavía en el siglo XVIII, sin franquearlos en dirección al Islam, Moscovia o el Extremo Oriente. Sin embargo, no se trata, según Braudel, de un obstáculo técnico, sino de una repugnancia cultural, puesto que existen fuera de Occidente circuitos densos y eficaces de letras de cambio, en beneficio de comerciantes musulmanes, armenios o indios. Estos circuitos también se detienen en los límites de las culturas respectivas. En cambio, en el interior de toda economía-mundo, las cartografías de la cultura y de la economía pueden diferir mucho, y hasta oponerse a veces. En los siglos XIII, XIV y XV, no son Venecia ni Génova son las que imponen su ley a la civilización de Occidente. Sería Florencia la que llevaría la voz cantante. En el siglo XVII, Amsterdam triunfa, pero el centro del barroco que invade a Europa es esta vez Roma, o si acaso Madrid. En el siglo XVIII, tampoco Londres se apodera del cetro cultural. De igual modo, a fines del siglo XIX y comienzos del XX, Francia, que va a la cola de Europa económicamente, sería el centro indudable de la literatura y la pintura de Occidente; y todavía hoy, el avance económico de Estados Unidos no los habría puesto a la cabeza del universo artístico y literario.

Sin embargo, y desde siempre, la técnica, la ciencia, se desarrollarían de manera privilegiada en las zonas dominadoras del mundo económico. El Arsenal de Venecia es el centro de la técnica, todavía en el siglo XVI. Holanda y luego Inglaterra heredan por turno ese doble privilegio. Este pertenece hoy a los Estados Unidos: «Pero la técnica no puede ser más que el cuerpo, no el alma, de las civilizaciones. Es lógico que sea favorecida por las actividades industriales y los altos salarios de las zonas más avanzadas de la economía. Al menos, ayer. Hoy, lo dudo» ${ }^{89}$, nos dice Braudel.

\footnotetext{
${ }^{88}$ Op. cit., III, p. 46.

${ }^{89}$ Op. cit., III, p. 49.
} 


\section{CUARTO DIÁlOGO: HISTORIA ADVERSUS PSICOLOGÍA}

Aunque sea un terreno en el que se mueva con poca pericia e interés, el ansia de totalidad en el método histórico de Braudel le lleva a introducir, junto con las explicaciones socioeconómicas, otras serie de explicaciones que a partir de los años sesenta en Francia se reúnen bajo la etiqueta de la historia de las mentalidades. Una vez más, Lucien Fevbre vuelve a cobrar en este aspecto un particular interés, porque, si bien es cierto que Braudel no constituye stricto sensu un discípulo suyo (su obra historiográfica está enfocada más bien a los aspectos materiales), al menos se dedica a difundir cada vez que se le presenta la ocasión ese libro fundacional que supone para los historiadores de las mentalidades El problema de la Incredulidad en el siglo XVI. La Religión de Rabelais ${ }^{90}$ : «Doy la bienvenida a la admirable tercera parte de la última gran obra de Lucien Febvre, La religión de Rabelais, en la que se esfuerza en poner de relieve todo lo que ha constituido el 'utillaje mental' de la época misma de Rabelais, el repertorio de términos, conceptos, razonamientos y sensibilidades a su alcance. Se trata en este caso de un corte en horizontal. Pero esta lección representa el resultado de una larga vida de trabajo, ya en su ocaso (1942). Lucien Febvre siempre pensó que algún día podría completarla, conferirle su plena 'dignidad'. Le faltaba, en efecto, distinguir tal corte, tal puesta a punto, del caso interesante pero en sí restringido de Rabelais; le quedaba por ver si, en suma, más tarde o más temprano, el mismo nivel había sido, o no, la norma; $y$, por último, le quedaba por estudiar cuándo, por qué, dónde, en qué medida se habían producido modificaciones ${ }^{91}$.

Lucien Febvre recogía en este libro las teorías de Lucien Lévy-Bruhl, quien aseguraba que los primitivos piensan de forma prelógica, que no utilizan racionalmente las categorías básicas del entendimiento como las del espacio, tiempo, objeto y causa, ni son capaces de aplicar el principio de contradicción, y que en resumen poseen una mentalidad prelógica. Febvre se limitaba a aplicar estas teorías a los hombres del siglo XVI. Sin embargo, sucedió que esta teoría se vino abajo al ser abandonada por su

\footnotetext{
${ }^{90}$ L. Febvre, El problema de la Incredulidad en el siglo XVI. La Religión de Rabelais, México, 1959 (París, 1936).

${ }^{91}$ F. Braudel, «Aportación de la historia de la civilización», en: La historia y las ciencias sociales, op. cit., p. 184.
} 
propio autor en la última etapa de su vida, en la que se dio cuenta de que su visión del primitivo formaba, en bastante proporción, parte de la ideología colonial europea, y al desarrollarse el conocimiento y cambiar los planteamientos antropológicos. Pero no por ello Braudel deja de reproducir el pensamiento de Febvre, aunque dándole un matiz materialista: «aunque estoy de acuerdo en que la inteligencia es, sin duda, portadora de sus propias explicaciones, de sus propios encadenamientos, me parece que, como lo sugiere el total de la obra de Lucien Febvre, también es aclarable por las inercias de la vida social y de la vida económica -por esas inercias particulares, de larga duración, tan características de las civilizaciones mismas- en el siglo XVI, sobre el que gravitan con un enorme peso, inconcebible a priori, tantos elementos antiguos».

¿Qué nos puede aportar, de cara al estudio de las civilizaciones, el análisis de las mentalidades? A decir de Braudel, mucho: «a cada época corresponde una determinada concepción del mundo y de las cosas, una mentalidad colectiva predominante que anima y penetra a la masa global de la sociedad. Esta mentalidad que determina las actitudes y las decisiones, arraiga los prejuicios, influye en un sentido o en otro los movimientos de una sociedad, es eminentemente un factor de civilización. Con mayor justificación que los accidentes o las circunstancias históricas y sociales de una época, es producto de antiguas herencias, de creencias, de temores, de viejas inquietudes, muchas veces inconscientes, en realidad, producto de una inmensa contaminación, cuyos gérmenes están perdidos en el pasado y transmitidos a través de generaciones y generaciones humanas $\rangle^{92}$. Las reacciones de una sociedad, frente a los acontecimientos del momento, frente a las presiones que se ejercen sobre ella, y a las decisiones que se le exigen, obedecerían menos a la lógica e incluso al interés egoísta, que a este imperativo no formulado, muchas veces informulable, que nacería del inconsciente colectivo. Es más, «lo más incomunicable que tienen las civilizaciones entre sí, lo que las aísla y las distingue mejor, es este conjunto de valores fundamentales de estructuras psicológicas. Y estas mentalidades son, igualmente, poco sensible al paso del tiempo. Varían con lentitud, sólo se transforman tras largas incubaciones, de las que también son poco conscientes» ${ }^{93}$.

\footnotetext{
${ }^{92} \mathrm{~F}$. Braudel, Las civilizaciones actuales, op. cit., p. 32.

${ }^{93} \mathrm{Ibid}$.
}

«CUADERNOS DE ESTUDIOS GALLEGOS», Tomo XLIX, Fascículo 115, Santiago 2002. 
A este respecto, la religión sería el rasgo predominante en el corazón de las civilizaciones, a la vez su pasado y su presente ${ }^{94}$. Y, sobre todo, claro está, en el corazón de las civilizaciones no europeas. En la India, por ejemplo, todos los actos cobrarían forma y justificación a partir de la vida religiosa, no de la racional. Por contra, parece que Occidente habría olvidado sus orígenes religiosos: «Pero más que de una ruptura operada por el racionalismo entre lo religioso y lo cultural, habría que hablar, de hecho, de una coexistencia entre laicismo, ciencia y religión, o, mejor dicho, de una serie de diálogos dramáticos o esperanzados, pero nunca interrumpidos, a pesar de las apariencias» ${ }^{95}$. El Cristianismo se afirmaría como una realidad esencial de la vida occidental, y a veces dejaría su huella en los ateos, aunque estos no siempre sean conscientes de ello. Así, por ejemplo, las reglas éticas, las actitudes ante la vida la vida y la muerte, el concepto de trabajo, el valor del esfuerzo, el papel desempeñado por las mujeres y los niños, serían otros tantos comportamientos que, aunque aparentemente no tienen nada que ver con el sentimiento cristiano, derivarían de él. De modo que «el cristianismo occidental ha sido, y continúa siendo, el componente más importante del pensamiento europeo, comprendido el pensamiento racionalista que se constituyó contra él, pero también a partir de él. A través de toda la historia de Occidente permanece en el centro de una civilización, a la que da vida incluso cuando se deja vencer o deformar por ella, y a la que engloba incluso cuando ésta se esfuerza en librarse de él... Un europeo ateo continúa siendo prisionero de una ética, de un comportamiento psíquico, poderosamente arraigados en una tradición cristiana $)^{96}$.

Sin embargo, el mito de la carrera hacia el racionalismo, con el que la filosofía europea desde Descartes y Kant convirtió al hombre culto europeo en cogito, sujeto transcendente (o en último caso, en un nuevo Dios),

\footnotetext{
${ }^{94}$ Aunque reconoce que «la realidad religiosa no es por sí sola la cultura entera; ésta también es espíritu, estilo de vida, en todos los sentidos de la expresión, literatura, arte, ideología, tomas de conciencia, etc». F. Braudel, Civilización material, economía y capitalismo. Siglos $X V$-XVIII, III, p. 45. Braudel continúa, por lo tanto, refiriéndose a la cultura (sinónimo de civilización) como la suma de una serie de bienes materiales y espirituales.

${ }^{95}$ Ibid.

${ }^{96}$ F. Braudel, Las civilizaciones actuales, op. cit., p. 292.
} 
es recogido por Fernand Braudel, como tantos otros historiadores, y sobre él sienta una de las bases de la originalidad (y en el fondo, de la superioridad) occidental: «la tendencia de la civilización occidental, desde el desarrollo del pensamiento griego, es la de un continuo hacia el racionalismo, y, por lo tanto, un igualmente continuo alejamiento de la vida religiosa. De ahí, su originalidad... Salvo contadas excepciones (ciertos sofistas chinos, ciertos filósofos árabes del siglo XII), estos alejamientos se han producido con más claridad en Occidente que en el resto del mundo. Casi todas las civilizaciones están invadidas, sumergidas en lo religioso, lo sobrenatural y lo mágico; viven en ellos desde siempre y de ello sacan las motivaciones más poderosas de su psiquismo particular. Tendremos ocasión de repetirlo más de una vez»» ${ }^{97}$.

Sin duda, Braudel está en deuda con esa etnografía y antropología europeas del siglo XIX y de la primera mitad del siglo XX, que había nacido con la clara finalidad de ensalzar los valores de la cultura europea, depositaria y legítima heredera del legado de la Razón, dejado por los griegos, a través de su contraposición con los pueblos primitivos y las civilizaciones inferiores. Al ser catalogadas estas poblaciones como animistas, mágicas o prelógicas, salían derrotadas en su imaginario encuentro con la Razón - celebrado en las mentes y los libros de los antropólogos o en las aulas de las Universidades- del mismo modo que habían sido conquistadas a nivel real. ¡Dejemos de hacer de una vez este tipo de distinciones! ¿Es que no es evidente que la distinción entre los hombres no está en su interior, en sus mentes, sino en el exterior, en las condiciones materiales, ecológicas, económicas y sociales de su existencia?

Como la propia civilización, las mentalidades no permanecen estáticas en el pensamiento de Fernad Braudel. Por lo general, avanzan de la mano. Sin embargo, a veces se producen inexplicables desequilibrios. Es el caso, por ejemplo, de la religión cartaginesa, en relación con su economía: «Los sacrificios humanos -acusación frecuentemente repetida por los latinos- son por lo demás reales: el topher, el santuario de Salambó, ha devuelto miles de vasijas que contienen osamentas de niños calcinados. Cuando Cartago quería conjurar un peligro, inmolaba a los hijos de sus ciudadanos más distinguidos para sus dioses... ¿Manchó la sangre de

\footnotetext{
${ }^{97}$ Op. cit., p. 33.
} 
las víctimas el nombre de Cartago? De hecho, todas las religiones primitivas conocieron prácticas semejantes. En este aspecto, Cartago sigue a los cananeos de Biblos o a los semitas de Israel: ¿no se encaminaba acaso Abraham a inmolar a Isaac? Lo asombroso en Cartago, sin embargo, es que mientras la vida económica corre hacia el porvenir, la vida religiosa se queda fija siglos y siglos atrás, ya que sus mismas 'revoluciones' -la del culto de Tanit en el siglo V- no la apartan en lo más mínimo de esta inhumana y aterradora piedad. El contraste es flagrante tras la apertura griega, que hace concordar al hombre con el mundo exterior. Aquí, una intensa vida comercial, incluso de espíritu 'capitalista', dice sin vacilar un historiador, va unida a una mentalidad religiosa retrógrada» ${ }^{98}$.

Por otra parte, la relación economía/mentalidad es puesta en cuestión otras ocasiones en la obra de Braudel. Así, por ejemplo, se refiere a la obra de Max Weber y de Werner Sombart, quienes hicieron surgir al capitalismo de la constitución de un tipo de espíritu. En este sentido, «la explicación 'idealista', unívoca, que hace del capitalismo la encarnación de cierta mentalidad, no es más que la puerta de salida que utilizaron, a falta de otra, Werner Sombart y Max Weber para escapar al pensamiento de Marx. En justicia, no estamos obligados a seguirlos. Sin embargo, yo no creo que todo sea material, o social, o relación social, en el capitalismo. Un punto queda a mi parecer fuera de duda: no puede proceder de un origen único y limitado; la economía, la política, la sociedad, la cultura y la civilización han tenido su participación. Y también la historia que a menudo decide en última instancia en cuanto a las relaciones de fuerza» ${ }^{99}$.

${ }^{98} \mathrm{~F}$. Braudel, El Mediterráneo. El espacio y la historia, op. cit., pp. 109-110.

${ }^{99} \mathrm{~F}$. Braudel, Civilización material, economía y capitalismo. Siglos XV-XVIII, II, p. 347. Toda explicación que ataña al capitalismo, tanto para Weber como para Sombart, equivale a exponer una superioridad estructural e indiscutible del «espíritu» occidental: «Cuando esta superioridad también proviene de los azares, de las violencias de la historia, de un mal reparto de los naipes a nivel mundial. La historia del mundo es inútil rehacerla por las necesidades de una causa, aún menos de una explicación. Pero ¿podemos imaginarnos por un instante que los juncos chinos hubieran doblado el Cabo de Buena Esperanza en 1419, en medio de la recesión europea que denominamos la Guerra de los Cien Años, y que la dominación del mundo hubiera jugado en favor del enorme país de este otro polo del universo de las poblaciones densas?», op. cit., II, p. 506. En esta perspectiva, Fernand Braudel tampoco niega, ni mucho menos, la superioridad estructural e indiscutible del «espíritu» occidental.

«CUADERNOS DE ESTUDIOS GALLEGOS», Tomo XLIX, Fascículo 115, Santiago 2002. 
Justifica, en cierta medida, esta relación, porque «no hay nada más natural que en 1904 Max Weber y Werner Sombart en 1912 tengan la impresión de estar, en Europa, en el centro necesario del mundo de la ciencia, de la razón, de la lógica» ${ }^{100}$.

Un último apunte, referido a la evolución mental humana: en este caso, sincronía y diacronía son conjugadas para elaborar un modelo evolutivo, en absoluto original, que serviría para poner en relación tres presuntas realidades de civilización: a saber, las creencias primitivas, la religión y la ideología, tres pasos en el trayecto hacia el racionalismo: «toda civilización se presenta a nosotros mediante capas superpuestas, vivientes y hostiles unas a otras. En profundidad, las creencias y supersticiones primitivas llevan una dura vida. Por encima de ellas las religiones organizadas, coherentes, que desde muy pronto se convirtieron en superestructuras conquistadoras, imperiosas, tenaces: en Francia, el druidismo, el paganismo, el cristianismo triunfante... La ideología, en el sentido más amplio, se desarrolla más tarde». Habría que observar esas realidades amontonadas en la vertical. En todo momento habría superposición abajo arriba: civilizaciones primitivas, religiones, ideologías. Estas realidades lucharían y se reemplazarían con una gran lentitud. Sin embargo, de hecho, se trata de un combate estructural (en el sentido braudeliano de la palabra). Estas realidades «se entregan a un combate perpetuo, el del hombre frente a sus esperanzas y a sus angustias. De una forma o de otra, ¿no son de igual naturaleza?» ${ }^{101}$. La fórmula «Dios ha muerto», le parece absurda a Braudel: «Dios no puede morir. O mejor dicho, el hombre no puede vivir sin su imagen, sin el inmenso espejo en que proyecta sus esperanzas, sus incertidumbres, sus ignorancias crueles. Los hombres del año 2000 serán todavía supersticiosos, todavía creyentes, todavía partidarios del pensamiento libre. Porque no dejarán de ser hombres» ${ }^{102}$. No deja de ser curioso que Braudel tan materialista, por lo general, a lo largo de su obra, introduzca, al final de sus días (la cita es de 1983) esta nota espiritualista, de tipo toynbeeano de las que él tanto se mofaba.

\footnotetext{
${ }^{100}$ Ibid.

${ }^{101}$ F. Braudel, Escritos sobre la Historia, op. cit., p. 141.

${ }^{102}$ Op. cit., p. 142.
} 